7. Reprod. Fert. (1975) 42, 319-324

\title{
THE ANTIFERTILITY ACTIVITY OF 2-(ISOPROPYLAMINO) ETHANOL IN THE MOUSE
}

\author{
C. M. HETHERINGTON \\ Clinical Research Centre, Watford Road, Harrow HA1 $3 U \mathcal{J}$
}

(Received 4th Fuly 1974)

\begin{abstract}
Summary. Intraperitoneal administration of 2-(isopropylamino) ethanol on the 3rd day of pregnancy reduces the extent of the decidual cell reaction induced by the blastocyst and can cause the death of the conceptus by the 6 th day of pregnancy. Evidence is presented to support the theory that the compound administered in this way has a direct effect on the conceptus.
\end{abstract}

\section{INTRODUCTION}

The compound 2-(isopropylamino) ethanol (PAE) is one of a number of simple amino alcohols which possess antifertility activity (Longenecker \& Gallo, 1972; Morrow \& co-authors, 1973). These compounds lack hormonal activity and have been reported to have embryotoxic effects in the rat as well as an action on the endometrium which prevents fetal development (Longenecker \& Gallo, 1972). It was of interest to extend this work to observations on the mouse with a view to understanding the mode of action of this compound.

\section{MATERIALS AND METHODS}

The hydrochloride salt of PAE in aqueous solution $(10 \mathrm{mg} / \mathrm{ml})$ was used in all experiments. The PAE was administered by intraperitoneal injection and control mice received an equal volume of distilled water at the same time as the mice in the experimental groups. Mice of the $\mathrm{CBA} / \mathrm{Ca}$ strain bred at the Clinical Research Gentre were used in all experiments.

\section{Effect on decidualization}

Pregnant female mice were injected with $0.5 \mathrm{mg}$ or $1.0 \mathrm{mg}$ PAE on the 3 rd day of pregnancy (Day 1 was the day on which a vaginal plug was found). Controls received $0 \cdot 1 \mathrm{ml}$ distilled water. Mice were killed on the 7 th day. Decidual tissue was dissected from the uterus as described previously (Hetherington, 1971). The mean decidual weight per implantation site was calculated.

Females mated with vasectomized males were injected with $1.0 \mathrm{mg}$ PAE on the 3rd day of pseudopregnancy at 09.00 hours. On the 4th day, at 13.00 hours, $10 \mu \mathrm{l}$ arachis oil were injected into the lumen of each uterine horn in order to induce the formation of deciduomata (Finn \& Hinchliffe, 1965). The mice were killed on the 7th day of pseudopregnancy, and their uteri were weighed. 
Other mice were ovariectomized and 2 days later they were placed on the hormone regimen (see Table 1) described by Finn \& Martin (1972). These mice received $1.0 \mathrm{mg}$ PAE on either Day 7 or Day 8 at 09.00 hours. On Day 8 , at 13.00 hours, $10 \mu \mathrm{l}$ arachis oil were injected into each uterine horn. The animals were killed on Day 11 and their uteri were weighed.

\section{Fetal and placental weights}

Pregnant mice were injected with $1.0 \mathrm{mg}, 0.5 \mathrm{mg}$ or $0.25 \mathrm{mg}$ PAE on the 3rd day of pregnancy. Controls received $0.1 \mathrm{mI}$ distilled water. On the 18th day of pregnancy, the mice were killed. Placentae and fetuses were dissected free from their membranes, blotted lightly and weighed. Early, middle and late deaths (McLaren \& Michie, 1959) were recorded and the mean placental and fetal weights for each female were calculated. Differences between groups were analysed by the regression of fetal weight and placental weight on the number of live fetuses on the 18th day.

Table 1. Hormonal regimen developed by Finn \& Martin (1972) for the sensitization of the uteri of ovariectomized mice to a decidual stimulus

\begin{tabular}{l|ccccccccccc}
\hline & 1 & 2 & 3 & 4 & 5 & 6 & 7 & 8 & 9 & 10 & 11 \\
\hline Treatment & $\mathrm{E}$ & $\mathrm{E}$ & $\mathrm{E}$ & - & - & $\mathrm{Pe}$ & $\mathrm{Pe}$ & $\mathrm{Pe}^{*}$ & $\mathrm{P}$ & $\mathrm{P}$ & $\mathrm{K}$ \\
\hline
\end{tabular}

$\mathrm{E}=100 \mathrm{ng}$ oestradiol; $\mathrm{P}=1 \mathrm{mg}$ progesterone; $\mathrm{e}=10 \mathrm{ng}$ oestradiol; $\mathrm{K}=$ autopsy.

* Injection of $10 \mu \mathrm{l}$ arachis oil into each uterine horn.

Embryo culture in vitro

Preimplantation embryos were flushed from the uterus on the 4th day of pregnancy. The embryos were cultured in modified Brinster's medium (Bowman \& McLaren, 1970), and PAE was added to the medium at concentrations of $125 \mu \mathrm{g}, 11.5 \mu \mathrm{g}, 1.25 \mu \mathrm{g}, 125 \mathrm{ng}$ and $12.5 \mathrm{ng} / \mathrm{ml}$. A further series of embryos was obtained on the 4th day of pregnancy from mice previously injected on the 3rd day with $1.0 \mathrm{mg}$ PAE.

\section{Histology}

Mice were killed on the 5th, 6th and 7th day of pregnancy after injection with $1.0 \mathrm{mg}$ PAE on the 3rd day. The uteri were removed and after fixation in formol saline, transverse sections were stained with haematoxylin and eosin and compared with similar sections from control mice.

\section{RESULTS}

When PAE was given to mice on the 3rd day of pregnancy, it resulted in a significant reduction in the weight of decidual tissue on the 7 th day $(P<0.001)$. This reduction was dose-dependent (Table 2). There was no effect on the number of implantation sites. 
When $1.0 \mathrm{mg}$ PAE was given to pseudopregnant mice on the 3rd day of pseudopregnancy, it had no significant effect on the weight of decidual tissue induced by the intraluminal injection of arachis oil (Table 3). Similarly, PAE failed to have a significant effect on the decidual response in mice maintained on the artificial hormone regimen (Table 4).

Table 2. Effect of PAE on decidual weight in mice on the 7th day of pregnancy

\begin{tabular}{c|c|c|c|c}
\hline $\begin{array}{c}\text { Dose of } \\
P A E \\
(\mathrm{mg})\end{array}$ & $\begin{array}{c}\text { No. of } \\
\text { mice }\end{array}$ & $\begin{array}{c}\text { Wt of mouse } \\
(\mathrm{g})\end{array}$ & $\begin{array}{c}\text { No. of } \\
\text { implantation } \\
\text { sites }\end{array}$ & $\begin{array}{c}\text { Decidual wt } \\
(\mathrm{mg})\end{array}$ \\
\hline 0 & 9 & $22 \cdot 6 \pm 0.5$ & $6.9 \pm 0 \cdot 3$ & $4 \cdot 64 \pm 0.27$ \\
0.5 & 9 & $21.4 \pm 0.4$ & $6.9 \pm 0 \cdot 4$ & $4.18 \pm 0.16$ \\
1.0 & 7 & $22 \cdot 1 \pm 0.4$ & $7.9 \pm 0 \cdot 6$ & $3.33 \pm 0.12$ \\
\hline
\end{tabular}

Values are given as Mean \pm S.E.

Table 3. Effect of PAE on the decidual cell response induced by the intraluminal injection of archis oil

\begin{tabular}{l|c|c}
\hline \multicolumn{1}{c|}{ Dose } & No. of mice & $\begin{array}{c}\text { Uterine wt in mg on } \\
\text { 7th day of pregnancy } \\
\text { (Mean } \pm \text { S.E. })\end{array}$ \\
\hline Control & 4 & $485 \cdot 8 \pm 38.9$ \\
$1.0 \mathrm{mg}$ PAE & 6 & $474.3 \pm 46.3$ \\
\hline
\end{tabular}

Table 4. Effect of PAE on the decidual response of mice maintained on an artificial hormone regimen

\begin{tabular}{c|c|c|c}
\hline $\begin{array}{c}\text { Day of injection } \\
\text { of PAE (see Table 2) }\end{array}$ & $\begin{array}{c}\text { Dose of } \\
P A E(\mathrm{mg})\end{array}$ & $\begin{array}{c}\text { No. of } \\
\text { mice }\end{array}$ & $\begin{array}{c}\text { Uterine wt in mg on } \\
7 \text { th day of pregnancy } \\
\text { (Mean } \pm \text { S.E. })\end{array}$ \\
\hline 9 & $1 \cdot 0$ & 5 & $414 \cdot 8 \pm 35 \cdot 2$ \\
& 0 & 5 & $349 \cdot 8 \pm 35 \cdot 5$ \\
10 & $1 \cdot 0$ & 6 & $442.5 \pm 49 \cdot 6$ \\
& 0 & 5 & $461 \cdot 0 \pm 37 \cdot 3$ \\
\hline
\end{tabular}

The administration of $1.0 \mathrm{mg}$ PAE on the 3rd day of pregnancy resulted in the death of all implantations. Subsequent investigation showed that the decidual tissue found on the 7 th day of pregnancy became necrotic by the 10th day and was shed by way of the vagina. Injection of $0.5 \mathrm{mg}$ PAE resulted in the early death of $61.5 \%$ of implantations, but $0.25 \mathrm{mg}$ PAE had no discernible effect on the course of pregnancy (Table 5). The mean placental weights and mean fetal weights, adjusted by regression analysis for variations in litter size using the pooled within-group regression coefficients, did not differ significantly (placental weight, $\mathrm{F}=0 \cdot 5$; fetal weight, $\mathrm{F}=0 \cdot 1$, d.f. $=2$ and 16 ). The difference in mean placental weight and mean fetal weight between groups, therefore, may be accounted for by the differences in litter size. 
Histological investigation indicated that the embryos died between the 5 th and 6th day of pregnancy.

Embryos cultured in concentrations of PAE greater than $125 \mathrm{ng} / \mathrm{ml}$, failed to survive as long as controls. When embryos were removed on the 4th day from mice which had been injected with $1.0 \mathrm{mg}$ PAE $24 \mathrm{hr}$ earlier, they failed to survive for more than $36 \mathrm{hr}$, while control embryos survived for $120 \mathrm{hr}$. On the morning of the 4th day of pregnancy, some embryos were morulae and some blastocysts. There was apparently no effect of PAE on blastulation in vitro or in vivo.

Table 5. The effect of PAE on placental weight and fetal weight on the 18th day of pregnancy

\begin{tabular}{|c|c|c|c|c|c|c|c|}
\hline $\begin{array}{c}\text { Dose } \\
\text { of } P A E \\
(m g)\end{array}$ & $\begin{array}{c}\text { No. of } \\
\text { mice }\end{array}$ & $\begin{array}{r}D e \\
\text { Early }\end{array}$ & $\begin{array}{l}\text { ths in pre } \\
\text { Middle }\end{array}$ & $\begin{array}{l}\text { ancy } \\
\text { Late }\end{array}$ & $\begin{array}{l}\text { No. of } \\
\text { live } \\
\text { fetuses }\end{array}$ & $\begin{array}{l}\text { Placental } \\
w t(m g)\end{array}$ & $\begin{array}{c}\text { Fetal wt } \\
(m g)\end{array}$ \\
\hline 0.25 & 6 & $\begin{array}{r}0.3 \\
\pm 0.3\end{array}$ & $0 \cdot 0$ & $\begin{array}{r}0.2 \\
\pm 0.2\end{array}$ & $\begin{array}{r}6.5 \\
\pm 0.5\end{array}$ & $\begin{array}{l}102.3 \\
\pm 5.3\end{array}$ & $\begin{array}{r}634 \cdot 7 \\
\pm 20 \cdot 3\end{array}$ \\
\hline 0.5 & 6 & $\begin{array}{r}4.0 \\
+0.7\end{array}$ & 0.0 & 0.0 & $\begin{array}{r}2.5 \\
\pm 0.2\end{array}$ & $\begin{array}{r}118.9 \\
\pm 4.4\end{array}$ & $\begin{array}{r}670 \cdot 9 \\
\pm 15 \cdot 6\end{array}$ \\
\hline 1.0 & 6 & - & - & - & 0.0 & - & - \\
\hline 0.0 & 8 & $\begin{array}{r}1.0 \\
\pm 0.4\end{array}$ & 0.0 & $\begin{array}{c}0.1 \\
\pm 0.17\end{array}$ & $\begin{array}{r}6.8 \\
+0.7\end{array}$ & $\begin{array}{l}106 \cdot 6 \\
\pm 2 \cdot 4\end{array}$ & $\begin{array}{r}633.8 \\
\pm 14.6\end{array}$ \\
\hline
\end{tabular}

Results expressed as Means \pm S.E.

Cell counts carried out on blastocysts recovered from females $30 \mathrm{hr}$ after treatment with $1.0 \mathrm{mg}$ PAE on the 3rd day did not suggest that the rate of cell division was affected. In eight mice treated with PAE, there were $26 \cdot 6 \pm 2 \cdot 3$ cells, whereas in eight control mice there were $28 \cdot 1 \pm 2 \cdot 1$ cells.

\section{DISCUSSION}

Swift \& Flack (1973) reported that PAE given orally to rats for the first 5 days of pregnancy reduced the extent of the decidual response to arachis oil. In the present study, the mice received PAE intraperitoneally only on the 3rd day of pseudopregnancy. When administered in this way to pseudopregnant animals or to those receiving hormones, there was apparently no effect on the deciduomata induced by arachis oil.

Treatment with PAE was found to inhibit the development of mouse embryos. This is in agreement with data reported for the rat. The time of action of this compound, however, differs in these two species. Swift \& Flack (1973) found that, after the oral administration of PAE $(50 \mathrm{mg} / \mathrm{kg}$ ) on the $3 \mathrm{rd}$ day of pregnancy, $75 \%$ of rat embryos died between the 11 th day and term. Development up to the 8th day of pregnancy was normal. By contrast, mouse embryos affected by PAE died between the 5th and 6th day of pregnancy, and no deaths attributable to PAE were found after this time. As PAE had no apparent effect on the induction of deciduomata by arachis oil, it is likely that blastocyst 
development was affected in that the ability of the blastocyst to induce decidual tissue was impaired. In the mouse, the decidual cell reaction is induced on the 4th day of pregnancy, the only time at which the uterus is able to respond to the induction stimulus. It is likely, therefore, that PAE administered on the 3 rd day of pregnancy has an effect on the blastocyst by the 4th day. Blastulation, both in vivo and in vitro, however, was not affected.

It has been postulated that decidual tissue provides protection for the conceptus from the mother's normal immunological defence mechanisms during the early phases of implantation (Kirby, Billington \& James, 1966) and it has been shown that prior immunization of the mother to paternal antigens can reduce the extent of the decidual cell reaction (Clarke \& Hetherington, 1971). It is possible, therefore, that the reduction in the amount of decidual tissue is such that the maternal immunological defence mechanisms are able to terminate development by the 6th day of pregnancy. In the present study, however, there was a $28 \%$ decrease in decidual weight between the controls and those mice receiving $1.0 \mathrm{mg}$ PAE. In the study of Clarke \& Hetherington (1971), there was a decrease of $30 \%$ resulting from immunization to paternal strain antigens, but the reduction in decidual weight did not prevent the successful outcome of pregnancy. It seems probable, therefore, that the failure of the embryo to develop beyond the 6th day of pregnancy is the result of the action of PAE on the embryo per se and that the reduction in the decidual cell reaction is an indication of this action, but is not a direct cause of the developmental failure.

The work of Hetherington (1971), Clarke \& Hetherington (1971) and Clarke (1971) suggests that a correlation may exist between decidual weight on the 7th day of pregnancy and fetal weight on the 18th day. In the present study, however, when allowance is made for differences in the number of live fetuses, PAE failed to affect either fetal or placental weight.

It may be concluded that PAE given intraperitoneally on the 3rd day of pregnancy can inhibit gestation in the mouse and appears to have a direct effect on the conceptus.

\section{ACKNOWLEDGMENTS}

I am grateful to Beecham Research Laboratories, Harlow, for the 2-(isopropylamino) ethanol, and I should like to thank Mr J. Culverhouse for his technical assistance, and Dr C. A. Finn for his advice.

\section{REFERENCES}

Bowman, P. \& McLaren, A. (1970) Viability and growth of mouse embryos after in vitro culture and fusion. F. Embryol. exp. Morph. 23, 693-704.

GLARke, A. G. (1971) The effects of maternal pre-immunization on pregnancy in the mouse. F. Reprod. Fert. 24, 369-375.

Giarke, A. G. \& Hethernngton, C. M. (1971) Effects of maternal preimmunization on the decidual cell reaction in mice. Nature, Lond. 230, 114-115.

Finn, G. A. \& Hinchlirfe, J. R. (1965) Histological and histochemical analysis of the formation of implantation chambers in the mouse uterus. F. Reprod. Fert. 9, 301-309.

FinN, G. A. \& MARTIN, L. (1972) Endocrine control of the timing of endometrial sensitivity to a decidual stimulus. Biol. Reprod. 7, 82-86. 
Hetherington, G. M. (1971) The decidual cell reaction, placental weight, foetal weight and placental morphology in the mouse. F. Reprod. Fert. 25, 417-424.

KirRY, D. R. S., Billington, W. D. \& James, D. A. (1966) Transplantation of eggs to the kidney and uterus of immunized mice. Transplantation, 4, 713.

Longenecker, D. E. \& Gallo, D. G. (1972) Studies on the mechanisms of the postcoital antifertility actions of two aminoalcohols in the rat. Biol. Reprod. 7, 123-124.

MCLAREN, A. \& Michie, D. (1959) Superpregnancy in the mouse. 1. Implantation and foetal mortality after induced superovulation in females of various ages. F. exp. Biol. 36, 281-300.

Morrow, D. F., Johnson, P. G., Torabi, H., Williams, D., Wedding, D. L., Graig, J. W., Majewski, R. F., Braszeton, J. P. \& Gallo, D. G. (1973) Antifertility activity of some $\beta$-amino alcohols. F. med. Chem. 16, 736-739.

SwiFT, P. J. \& FLACK, J. D. (1973) The post-coital antifertility action of 2-isopropylamino-ethanol in the rat. F. Reprod. Fert. 35, 625-626. 